\title{
Dash for Gas:
}

\section{Climate Change, Hegemony and the Scalar Politics of Fracking in the UK}

\begin{abstract}
:
This paper investigates the political contestation over hydraulic fracturing of shale gas, or 'fracking', in the UK. Based on an analysis of four public inquiries we show how both proponents and opponents of fracking employed scaling to mobilize interests by connecting (or disconnecting) fracking to spatial and temporal scales. Our analysis explains how a fossil fuel hegemony was reproduced by linking local and specific benefits to nationally or globally recognized interests, such as, employment, energy security and emission reductions. The paper contributes to recent debates on environmental political contestation by showing how scaling enables the linkage of competing interests by alternating between spatial (e.g. local vs. global) and temporal (e.g. short term vs. long term) horizons. We argue that scaling allows dominant actors to uphold contradictory positions on climate change, which contributes to explaining the current disastrous political climate impasse.
\end{abstract}

Keywords: climate change, fracking, scaling, hegemony, politics, discourse 


\section{Introduction}

Over the last several decades, climate change has rapidly emerged as a pressing political, social and economic concern. Two centuries of fossil-fuel based industrialisation have altered the chemistry of the atmosphere and oceans in ways that threaten the complex web of life on this planet. These actions have already increased average global temperatures by more than 1 degree Celsius above pre-industrial levels (Mann, 2014), with projected warming likely to exceed 4 degrees Celsius later this century (IPCC, 2013). The physical impacts of this humaninduced climate perturbation include storms, droughts and wildfires of increasing ferocity, the melting of ice-caps and glaciers, rising sea-levels, ocean acidification and widespread species extinction. Indeed, scientists suggest these levels of climate change are likely incompatible with continued human civilization (New, Liverman, Schroeder and Anderson, 2011).

However, meaningful responses to the climate crisis remain piecemeal and insufficient. A key part of the problem relates to the need to radically reduce fossil fuel use if the world is to avoid dangerous climate change, while national governments and key industries remain tied to the growth of fossil-fuel driven economies. Thus, rather than stepping back from the abyss, our economic and political masters double down on the fossil fuels bet. This 'creative selfdestruction' is evident in escalating greenhouse gas (GHG) emissions and the promotion of ever more innovative ways to extract fossil fuels through, for example, deep-water and Artic oil drilling, tar sands processing, and hydraulic fracturing of shale gas (Wright and Nyberg, 2015).

An important characteristic of the complexity of climate change is that practices and policies operate on different spatial and temporal horizons. Climate change as a physical phenomenon operates at a planetary scale, while human responses remain tied to national, regional and organisational processes in which different actors seek to minimise actions which impede their short-term interests (Levy and Spicer, 2013; Slawinski, Pinkse, Busch and 
Banerjee, 2017). This scaling down of climate change into immediate and local practices is evident in national and regional political debates over resource use, industry development and economic growth (Bulkeley and Newell, 2015). Government and corporate responses to climate change thus highlight the centrality of spatial and temporal scales in the politics of resource use and sustainability.

In this paper we explore how the political process of scaling is carried out by actors in a national debate over the future development of a new fossil-fuel industry in the United Kingdom (UK); hydraulic fracturing of shale gas (aka 'fracking'). Fracking links local activities to planetary consequences (fossil fuels account for about 65 per cent of all global anthropogenic GHG emissions (IPCC, 2014)). Importantly, however, the decisions about whether and how such resources are exploited hinge on political contestations at local, regional, industry and national levels. We analyse four public inquiries and subsequent reports debating fracking in the UK. The analysis shows how scaling is employed to mobilize support for, or resistance towards, fracking through spatial and temporal connections and disconnections. Our findings explain how political and business elites maintain the fossil fuel hegemony by connecting different spatial and temporal scales to financial interests, energy security and even climate change concerns

We make three contributions. First, we contribute to discussions on sustainability in organization and management theory (OMT) (Shrivastava, 1995; Banerjee, 2003), by explaining the continuous justification of fossil fuels. Fracking is a unique and valuable case in that a fossil fuel is used pragmatically to address concerns about carbon emissions. Second, we contribute to OMT debates on corporate political activity and environmental contestation (Levy and Egan, 2003; Maguire and Hardy, 2009; Barley, 2010), by showing how spatial and temporal scales are employed to mobilize support for a dominant position. We add to this literature by explaining how the complexity around environmental issues, such as climate 
change, enable political manoeuvring by constructing different scales. Third, and more specifically, we contribute to the emerging neo-Gramscian literature within OMT by employing scaling to explain the workings of equivalence claims among different and fragmented interests (Dey, Schneider and Maier, 2016; Nyberg, Spicer and Wright, 2013; van Bommel and Spicer, 2011). Different interests can be accommodated by constructing scales to create overlap among differences; for example, the claim that fracking supports both local employment and global action on climate change.

\section{Climate change politics}

In response to early critique of OMT's lack of engagement with climate change (Goodall, 2008), there is now a growing body of work examining organizational processes underlying climate change (in)action (Howard-Grenville, Buckle, Hoskins and George, 2014; Slawinski et al., 2017; Wittneben, Okereke, Banerjee and Levy, 2012; Wright, Nyberg, De Cock and Whiteman, 2013). This literature has sought to explain how business corporations have responded to climate change in terms of market, regulatory and reputational risk (Hoffman, 2005), and to what extent organizations and managers are able to balance the competing tensions of market and environmental needs (Van der Byl and Slawinski, 2015; Whiteman, Walker and Perego, 2013). Failure to take effective action in mitigating GHG emissions has resulted in more critical analyses trying to explain humanity's fossil fuel addiction (Levy and Spicer, 2013), as well as the limitations of a reliance on business and market responses to the climate crisis (Wright and Nyberg, 2017).

A prevalent conceptualization in OMT to explain the politics underlying environmental contestations such as climate change, has been the discussion of hegemony (Levy and Egan, 2003; Nyberg et al., 2013; Wittneben et al., 2012; Prasad and Elmes, 2005). Hegemony involves the organization of consent through 'intellectual and moral leadership' (Gramsci, 
1971, p. 57). According to Gramsci (1971, pp. 325-326), ruling classes produce social consent without the use of violence or coercion by creating a 'common sense' - an ideological conception of the world that is taken for granted in creating the future. Hegemony is established by winning over agents and groups to this dominant ideological position. This 'war of position' is won through forging relationships and agreements among different identities and interests. In creating a 'unity of opposites and distincts' the new common sense forms the basis of a 'historical bloc' of actors who understand themselves as sharing interests (Gramsci, 1971, p. 137).

In developing the concept of hegemony, Laclau and Mouffe (2001) broke with Gramsci's Marxist class essentialism by arguing that class is one identification among others, and that hegemony consists of the articulation of relationships between a diverse set of constructed identities and interests. Hegemony is then employed to understand the basic constitution of politics in how particular meanings of an issue - e.g. fracking - become accepted as 'natural'. The politics of establishing a historical bloc requires continuous political work in forming strategic alliances. Below, we develop this neo-Gramscian conceptualization of hegemony to explain political contestation, and then argue that the concept of scaling can further our understanding of the perpetuation of hegemony by explaining how different and competing interests can be repressed using scaling.

\section{Hegemony in political contestations}

There are two strands of neo-Gramscian theorizing within OMT literature, emphasizing (a) the dominance of a given representation of the world (Levy, Reinecke and Manning, 2016; Levy and Egan, 2003), and (b) the processes or mechanisms through which this dominance is established (Nyberg et al., 2013; van Bommel and Spicer, 2011). While both strands recognize the interdependence between (a) the relative dominance of a given form of production or world 
order, and (b) the processes through which this hegemony is produced; the former explains the reciprocal stability of hegemony and the latter describes how diverse identities and interests are discursively constructed as common sense.

First, the concept of hegemony is useful for explaining the structured coherence and stabilized configurations within institutional fields (Levy and Egan, 2003) or value regimes (Levy et al., 2016) in a historical bloc. This secures the dominance of a given order aligning economic, ideological and organizational forces, which can explain the fossil fuel industry's ability to preserve its dominance (Levy and Egan, 2003). Hegemony explains path dependency and path creation over time by showing how, when challenged, the dominant structural formation can accommodate threats through compromise and concession (Levy et al., 2016). Hegemony here explains how a regime or bloc dominates a discussion or practice by winning subjects' consent or securing their compliance. However, the perspective provides limited insight into how these diverse interests and identities are linked or forged.

The second neo-Gramscian perspective in OMT attends specifically to the operations of linking together disparate demands (Nyberg et al., 2013). Drawing primarily on Laclau and Mouffe's (2001) reconstruction of Gramsci's concept of hegemony to analyse politics (Howarth, 2015), this literature is concerned with the study of struggles beyond a priori class nominations (Contu, Palpacuer and Balas, 2013; van Bommel and Spicer, 2011; O’Doherty, 2015; Dey et al., 2016). For example, Nyberg et al. (2013) show how corporations synchronize their interests with those of citizens in influencing the debate on climate change to benefit corporate agendas. This involved creating 'chains of equivalence' (Laclau and Mouffe, 2001) between different and fragmented groups in society by recasting them as active constituents, responsible consumers, ethical employees and ecopreneurs (Nyberg et al., 2013). This is in contrast to the logic of 'difference' that separates identities and interests by highlighting their 
divergent concerns. This research shows how subjects have multiple and often competing interests and identities that dominant actors can exploit for hegemonic purposes.

While recognizing the discursive construction of interests, these studies of political contestation have focused on a societal 'war of positions', where dominant and subordinate groups are pitched against each other (Levy et al., 2016; Levy and Newell, 2002), as well as how dominant actors connect with wider popular interests and identities in creating a hegemonic historical bloc (Levy and Spicer, 2013; Nyberg et al., 2013). Political contestation is explained using an equivalent chain to expand the hegemonic formation to encompass differences in antagonistic struggle with a chain of difference presented as dissimilar (Laclau, 2005). The split identity or interest allows for hegemonic expansion without breaking the chain of equivalence (Nyberg et al., 2013), but it requires a high degree of antagonism. In the next section, we argue that scales can be employed for hegemonic projects by scaling interests to span competing or fragmented interests while upholding a low degree of antagonism.

\section{Scalar politics in fossil fuel contestation}

Scales - ordered structures of space - are used to make sense of the social world. They are social constructions employed to assign meaning to our surroundings (Haarstad, 2014; Marston, 2000). Scales set things apart; they are linguistic categorizations that construct representations of the world (Springer, 2014, p. 404). They create naturalized spatial borders of relation and hierarchy - e.g. local versus global. The relations between scales are necessary to make sense of them; hence the 'local' is meaningful in relation to the 'global' (Herod, 2011). The discursive movements in connecting issues in scalar terms are significant in how societal problems are dealt with. For example, fossil fuel resources are extracted or fracked in particular places, while their consumption has global climate consequences, and the resources are 
governed by national and regional institutions. This creates complexity in governing crossscalar and competing interests.

Scales are generally territorial to some extent (Leitner, 1997). For example, a local scale can refer to a drilling site for fracking, which, horizontally can be related to another drilling site. While macro scales appear more abstract, they can also have spatial representations in, for example, the headquarters of the United Nations or multinational corporations. Scaling can then create vertical relationships between spatial and material locations. However, scaling can also be seen in a temporal sense, in that reference to material spaces are located in time. For example, proposals for new fossil fuel developments like coal mines, oil rigs or fracking sites are temporally placed in the future, in comparison to past or current fossil fuel activities. Scaling is a discursive process of producing spatial and temporal boundaries for understanding an object, such as, climate change or fracking.

Given that scales are socially constructed and based upon particular discourses, the production of contested objects becomes a political process. For example, the fossil fuel industry often justifies proposals for new developments, like fracking, by 'upscaling' the local challenge and drawing upon discourses surrounding international relations and 'energy security' (Jaspal and Nerlich, 2014). In a different movement, climate change activists can 'downscale' their discursive appeals by pointing to the local material consequences of fossil fuel development (e.g. local environmental destruction, community and indigenous threats). How we understand an issue and how it is addressed is therefore dependent on the scaling employed to define the problem.

Scalar politics involves the contestation of the dominant scaling of an issue; how the issue is spatially and temporally understood. Scales are strategically constructed for political agendas and ends (Brown and Purcell, 2005; Spicer, 2006), with scaling employed to constitute and stabilize hegemonic views of limited and natural resources (Swyngedouw and Heynen, 
2003). This is particularly pertinent to resource extraction, where there are conflicts over local (Banerjee, 2000), cross-scalar (Brown and Purcell, 2005), and temporal interests (Slawinski et al., 2017).

The concept of scaling can contribute to understanding political contestation by showing how the world is vertically and horizontally structured to create hegemony. More specifically, scaling can be employed to construct equivalence across scales and downplay difference in hegemonic projects. Through scaling, social actors can move the contestation to another scale in pursuit of their interests and, in so doing, downplay or avoid discussions of competing interests or difference. Thus, scaling allows us to structure the analysis in order to explain the workings of equivalence in the political contestation over fracking.

\section{Methods}

\section{Context}

A growing political debate has emerged in the UK over the future of energy security given the declining fortunes of North Sea gas, the closure of coal mining, and an increasing reliance on imported gas from Russia and Norway. Following the example of the United States (US), energy companies and UK politicians began promoting the idea that the UK could achieve future energy independence through the adoption of fracking (Department of Energy and Climate Change, 2010). Fracking is the process whereby gas and sometimes oil is extracted from shale rock formations deep underground. This involves the injection at high pressure of large volumes of water, sand and chemicals deep into the earth creating fractures in shale deposits enabling the gas/oil to be extracted. Developed in the 1950s, gas and oil fracking is not a new technology (North Sea oil and gas rigs have used hydraulic fracturing since the late 1970s), however over the last decade the use of large-scale horizontal fracking has increased 
significantly around the world, and is credited with precipitating an energy revolution in the US (Kitchen, 2014).

In the UK, the political contestation over fracking began in 2007 when Cuadrilla Resources was given a licence to conduct preliminary fracking operations at Preese Hall Farm near Blackpool. In April and May 2011, two seismic events precipitated by the fracking operation led to a Government restriction on fracking operations and significant media attention (Jowit and Gersmann, 2011). Environmental protestors stepped up their campaigns against fracking, and while the Government later lifted restrictions on fracking and emphasised its support for a domestic shale gas industry, the resulting public controversy led to the establishment of a series of parliamentary inquiries from 2011-2015 into the economic and environmental implications of gas fracking (see Table 1).

INSERT TABLE 1 ABOUT HERE

Official public inquiries are a common means through which governments and regulatory agencies seek to deal with politically contentious issues and crises, promote a preferred sense-making narrative, and seek to restore institutional legitimacy in a period of social tension (Brown, 2000; Topal, 2009). While popularly viewed as a means of discerning objective truth, researchers argue public inquiries act more as ceremonies which seek to depoliticise events, reassert ruling political myths and legitimate 'the actions and interests of dominant groups' (Brown, 2000, p. 45). Public inquiries are thus key arenas within which political hegemony is crafted.

In this paper we analysed the four public inquiries conducted by the UK Parliament into the proposed expansion of shale gas fracking. The first inquiry was launched on 24 November 2010 and held in session 2010-2012 by the House of Commons (HoC) Energy and Climate Change Committee. The inquiry examined the general issues surrounding shale gas 
development including 'the prospects of shale gas in the UK, the risks and hazards associated with shale gas, and the potential carbon footprint of large-scale shale gas extraction' (HoC, 2011a, p. 5). Following this, a second inquiry was held in 2012-2013 by the same HoC committee to ascertain the potential impact of shale gas for the UK and world energy markets, releasing its final report in April 2013 (HoC, 2013b). The third inquiry was ordered by the House of Lords (HoL) Economic Affairs Committee during 2013-2014 and focused specifically on the economic impact of shale gas and oil, with the stated purpose 'to stand back from the passion on both sides, and focus on the facts' (HoL, 2014a, p. 9). The final inquiry was led by the HoC' Environmental Audit Committee in January 2015. Unlike the economic focus of the earlier inquiries, this investigation focused more on the environmental implications of an expanded gas industry and sought to identify the extent to which fracking would be consistent with the UK's climate change obligations... and the environmental risks' (HoC, 2015, p.8).

All four of these inquiries received extensive written and oral evidence from a broad range of stakeholders including scientists and technical experts, industry and corporate executives, government ministers, regulatory officials, environmental non-government organisations (NGOs), and local community and environmental groups. As outlined in Table 2, the majority of inquiry participants fell into two broad categories; those supportive of the expansion of a UK shale gas industry, and those opposed to it, with a smaller group of largely technical experts neither expressing support nor opposition.

\section{INSERT TABLE 2 ABOUT HERE}

\section{Data collection and analysis}

Our data consists of the combined written evidence (WE), oral evidence (OE) and transcripts from the four inquiries, as well as each inquiry's final report and the relevant written 
Government response. As outlined in Table 1, taken together this amounted to over 1200 pages of document evidence.

Following the neo-Gramscian approach in OMT, we conducted a discursive analysis of the textual data (see e.g. Walton and Boon, 2014). With discourse, we refer to the structured collection of texts embodied in the practices of talking and writing (as well as a wide variety of visual representation and cultural artefacts) constituting social reality as these texts are produced, disseminated, and consumed (Grant, Hardy, Oswick and Putnam, 2004). Discourse analysis is then the practice of analysing these empirical texts to understand how a particular 'reality' is constituted to enable subjects to 'experience the world of objects, words and practices' (Howarth and Stavrakakis, 2000, p. 4). In our study, the textual unit of analysis was the oral and written evidence produced for the inquiries as well as the four reports produced by the UK Parliament and the Government responses to each of the reports.

We initially analysed the textual data in a grounded manner in order to ascertain the key discourses emerging in the texts (Spicer and Fleming, 2007). This involved a descriptive analysis to understand how texts articulated fracking. Table 2 provides examples of groups vocal in the inquiries and their positions regarding the development of fracking in the UK. In the majority of cases, witness testimony would directly indicate support or opposition for fracking, for example, 'Those of us who support this issue need to get on the front foot' (HoL, 2014b, p. 240); or 'Please scrap these plans and respect people's health and property rights.' (HoC, 2015, Dianne Hogarth, WE, p. 2). However, in some cases, where support or opposition was not directly stated, further analysis deduced support or opposition from the context of what was being presented. Where testimonies were highly technical or seemingly impartial they were categorised as neutral. We then tabulated the data into a) the positions on fracking and b) the discourses employed to argue for and against fracking. We focused on how the proponents and opponents of fracking linked their position with discourses around for example, 'energy 
security', 'energy costs', 'transition fuel', 'employment' and 'climate change'. This initial analysis thus attended to 'what' discourses were used in arguing for and against the expansion of shale gas and fracking; i.e. 'the content of mobilization of diverse groups and interests' within the inquiries (Contu et al., 2013, p. 367). The analysis established a clear political frontier and the content of the discourses employed in the struggle.

In the second stage of our analysis, we examined the 'how' of the discursive constructions; i.e. 'the specific form through which alliances and alignments were realized' (Contu et al., 2013, p. 369). This analytical process attended to the strategies of a) forging identities and interests through a logic of equivalence and b) separating these through a logic of the difference (Laclau and Mouffe, 2001). For example, proponents linked fracking with a UK national interest of energy security and opponents separated fracking from meaningful action on climate change. Each connection and disconnection was then analysed in relation to what it achieved, i.e. what the discursive process was doing in connecting/disconnecting fracking with identities and interests. It was this analytical process that led us to the concept of 'scaling'. Thus, while we refer to scaling in the literature review above, this focus was the outcome of our empirical analysis of how fracking and climate change was related in the texts.

Following this focus, we then worked abductively between the texts and our interest in the discursive processes of scaling (Wodak, 2004). Scales were applied as a 'category of practice' by analysing the way in which the actors structured space within the employed discourses; i.e. how the actors used 'scale categories not just to interpret spatial politics, but to frame and define, and thereby constitute and organize, social life' (Moore, 2008, p. 218). For each different spatial and temporal scale (local, national and global), scalar politics make a connection/disconnection between actor interests. The analysis showed how each connection/disconnection was related to interests at a particular spatial and temporal scale for 
actors to identify with (see Table 3 and 4). Here we discerned differences in the temporality and tangibility of how scaling was linked to different interests.

INSERT TABLE 3 ABOUT HERE

INSERT TABLE 4 ABOUT HERE

\section{Findings}

Building the economic and environmental case for fracking

Across all four parliamentary inquiries, the UK Government and resource companies, as the key proponents of a future shale gas industry, sought to forge connections with citizens, communities and landholders by appealing to a set of common economic and environmental interests. These included appeals to the need for future energy security, reduced energy costs, jobs and investment, and responding to climate change concerns.

For instance, the discourse of energy security emphasised the risk of a reliance on uncertain imported gas and that fracking could provide supply certainty. As the HoL report argued, developing a domestic shale gas industry '... would be especially valuable given the continuing fall in output from the North Sea and Europe's reliance on Russia, its biggest gas supplier, highlighted by the crisis in Ukraine.' (HoL, 2014a, p. 5). Linked to these appeals to national energy security, proponents also emphasised how domestic shale gas would reduce energy cost pressures on consumers and industry. As the Minister for Energy proclaimed, 'It [shale gas] has the potential quite dramatically to reduce costs for our industry and for our domestic consumers.' (HoL, 2014b, p. 161)

The national interest was also paramount in claims that this new industry would generate significant employment and benefit UK economic competitiveness. For example, energy company Centrica emphasised how the expansion of a domestic shale gas industry in the UK 
could lead to annual investment of '..$£ 3.7 \mathrm{bn}$ a year and 74,000 jobs could be supported across the industry and its supply chain' (HoL, 2014b, p. 54). Other witnesses talked of the potential for a new shale gas industry to drive local economic growth in a manner similar to the earlier North Sea gas boom. As the CEO of IGas Energy proclaimed: '[the industry] will want to be based locally and close to where the operations are. That gives rise to the opportunity to create a new onshore version of Aberdeen somewhere in the UK, probably in the north-west' (HoL, 2014b, p. 87).

Aware of environmental criticism of fossil fuels, industry and government advocates for fracking also emphasised how shale gas was also a 'cleaner' fossil fuel with a lower emissions profile than coal. This promotion of shale gas was framed within a discourse of gas as a 'bridge fuel'; an energy source that could reduce national GHG emissions in the short-term as part of a broader transition towards renewable energy sources such as solar and wind power (HoC, 2011a, p. 30). Thus for advocates, opening the country to fracking offered a way in which shared climate change concerns (articulated in legislated emissions targets) could be more easily achieved.

By contrast, opponents to fracking placed far greater emphasis on the negative environmental consequences of shale gas production, differentiating the economic interests of the Government and energy companies from the environmental concerns of local communities and UK citizens. In particular, the growth of fracking was seen by opponents as potentially locking-in a new form of fossil fuel dependency at a time when the vast majority of fossil fuel reserves should stay in the ground. Indicative of this view, Nick Molho from WWF-UK emphasised the clear disjuncture between shale gas expansion and a habitable future climate: 'Dash for Gas infrastructure is incompatible with preventing the worst aspects of climate change.' (HoL, 2014b, p. 194). Indeed, opponents argued that the apparently lower emissions profile of shale gas was negated by research finding significant 'fugitive emissions' across the 
gas supply chain, and the likelihood that large-scale fracking would crowd-out investment in renewable energy technologies. Added to this, fracking opponents stressed how the expansion of shale gas would result in local environmental damage including groundwater contamination, air pollution, water shortages, and growing rural industrialisation. These claims emphasised a differentiation of interests between the powerful economic and political elites proposing fracking, and local communities which would bear the brunt of fracking's material impacts.

Thus, for advocates, fracking offered an economically beneficial and potentially lower carbon energy source that would provide energy security, economic growth and a way to achieve national emissions reduction targets. Fracking was made equivalent to recognized national interests of energy security and local interests of jobs. Proponents articulated a collective will and scaled up the political frontier towards Russia and avoided a national political frontier. For opponents, fracking would not only harm local environments and communities, but lock-in a future era of fossil fuel dependence just when the UK needed to radically decarbonise its energy system and invest in large-scale renewable energy technologies. The counter-hegemonic projects attempted to construct a chain of equivalence through global climate change and opposition to local environmental destruction. In this political battle over the future path of the UK's energy infrastructure, both advocates and opponents of fracking sought to link their concerns to local, national and global scales of debate. As we outline in the next sections, this involved complex processes of connection and disconnection to articulated interests.

\section{Scalar politics of fracking}

As national arenas of public policy debate, the four inquiries linked the local practice of fracking to broader national agendas of energy and climate politics. A first process of scaling thus involved attempts by fracking proponents and critics to engage in discourses which scaled- 
down from the national to the local level (see Table 3). For instance, a common scaling amongst industry and government emphasised the advantages that would flow to local communities from an expansion of fracking, in terms of jobs, cheaper energy prices, and financial incentives. As Lord Smith highlighted in the HoL inquiry, land-holders could benefit financially from hosting fracking wells on their properties, 'the industry launched a pilot scheme that will see local communities receive a one-off payment of $£ 100,000$ once exploratory drilling has begun. It is also consulting on a proposal for communities to receive a $1 \%$ share of revenue once a production has started.' (HoL, 2014b, p. 165). Fracking proponents sought to build connections by promoting the common financial interests they could share from the expansion of shale fracking. The legal and financial resources of government and corporations thus provided a ready means to promote equivalence in interests and forge connections in building hegemony over fracking.

By contrast, a countervailing movement was evident amongst environmental NGOs and activist groups who sought to differentiate the interests of government and industry from those of local communities and landholders in constructing a political frontier. This was particularly pronounced in the emphasis environmental groups placed on the risks that fracking posed for health and environmental well-being. As a joint submission by Friends of the Earth, Greenpeace and WWF emphasised in the HoL inquiry: 'in areas of water scarcity, the extraction of water for drilling and hydraulic fracturing...can have broad and serious environmental effects. It can lower the water table, affect biodiversity and harm the local ecosystem. It can also reduce the availability of water for use by local communities' (HoL, 2014b, p. 185). The opposition promoted a clear difference between the material interests of local communities on the one hand, and multinational resource companies and the UK Government on the other. Indeed, underlying much of this opposition was a strong theme of conflicting interests between political and economic elites in the prosperous south of England, 
and impoverished and vulnerable working-class communities in the North which would bear the environmental costs of fracking.

Beyond scaling down from national to local levels, a second process of scaling emphasised the links between national and global levels. For proponents focused on the economic and energy security aspects of fracking, linkages to global concerns stressed changing geopolitical and trade relationships, likely future movements in the price of oil and gas, and the potential of shale gas to rejuvenate British industrial competitiveness. For instance, resource company Cuadrilla argued the expansion of the fracking industry '...has the potential to re-energise a moribund economy, and provide a sense of self-determination and progress.' (HoL, 2014b, p. 71). The links between global trends in climate change policy and GHG emissions mitigation were also frequently enlisted by those seeking to make a case for the expansion of fracking. As industry group, the Energy and Utilities Alliance emphasised, 'Gas is also cleaner than both coal (power generation by 50\%) and oil (transportation by $25 \%$ ) so its use will enhance the ability of the UK to achieve its climate change obligations' (HoC, 2013a, p. 12). As a purportedly 'cleaner' fossil fuel, proponents stressed how the UK's ratification of the Kyoto Protocol now institutionalised within national emissions targets such as the Climate Change Act 2008, required a national policy of energy transition of which shale gas should form a part. It was thus in the national interest to continue with fracking developments.

Again however, such moves were challenged by environmental critics who differentiated the expansion of a new fossil fuel industry in the UK and the global imperative of rapid decarbonisation if the world was to avoid dangerous climate change. As Dr Jon Broderick from the Tyndall Centre for Climate Change Research emphasised at the final HoC inquiry, 'The central issue is: do we want to avoid dangerous climate change and how do we go about doing that? That then speaks to the exploration of all fossil fuels and our political processes around that. As far as I am concerned, that is the central issue here' (Dr Broderick, HoC, 2015, OE, p. 
20). Thus, the expansion of fracking was presented as diametrically opposed to the national interest in responding to the global challenge of climate change, with critics arguing that fugitive emissions negated fracking's 'green' promise and distracted from the need for large investments in renewable energy as a path to decarbonisation.

A third vertical scaling process evident in the data highlighted links between global and local issues. In challenging the proponents' claims of local economic benefits from a fracking revolution, critics stressed how future climate change impacts such as droughts and heatwaves would exacerbate local water shortages which would be further diminished by fracking. Indeed, critics argued that if fracking were to deliver the much-promised cheaper energy prices, this would simply encourage consumers to expand an energy profligate lifestyle further locking-in a climate change future. As Tony Bosworth from Friends of the Earth outlined in the HoC inquiry: 'If your question is about climate change, consumption of energy is a major issue so you may not necessarily want the prices to go down for everyone' (HoC, 2013b, p. 29).

While vertical scaling discourses linking (and differentiating) global, national and local levels, another discursive strategy involved horizontal scaling (see Table 4). In this process, actors connected, and disconnected, developments from within the same scalar level. For instance, a common movement amongst fracking proponents was to appeal to the example of the US experience as a model for the UK. Here scalar politics moved within the same national level through comparison and employed arguments based around the dramatic increase in domestic US gas and oil production that fracking had delivered; shifting the US from an energy importer to a net energy exporter. Proponents also argued fracking had allowed the US to reduce its national GHG emissions as the country shifted from coal to gas in electricity production. As energy company Scotia Gas argued before the HoC inquiry, 'Assuming climate change objectives are to reduce GHG emissions then it has been demonstrated that USA has reduced $\mathrm{CO}_{2}$ energy-related emissions to a 20-year low' (HoC, 2013a, p. 55). By contrast, 
critics antagonistically sought to break this horizontal linkage, questioning the veracity of the US comparison in terms of a differing economic and geological context.

\section{Scaling and temporalizing}

Beyond vertical and horizontal scales, actors within the parliamentary inquiries also utilised different temporality in justifying their arguments. For instance, fracking advocates temporally located their concerns with energy security, affordability and economic growth in the shortterm future and linked to immediate rewards (see Tables 3 and 4). For example, by constructing fracking as a 'bridge fuel' and a response to the uncertainties of imported oil and gas, fracking advocates could highlight their concern with the immediate interest of energy security and 'keeping the lights on' for British citizens: 'natural gas will necessarily play a major part in the UK's energy mix in the medium term (for both power generation and heat) if we are to keep the lights on ahead of the wider development of new nuclear and renewables' (HoL, 2014b, p. 307). This was aligned with the current and shared interest of British consumers in 'affordable energy', with shale gas portrayed as a more economically viable form of energy than rival renewable sources such as wind and solar. As Lord Ridley argued, 'I do worry that we are talking about spending $£ 100$ billion by 2020 and another $£ 200$ billion on renewable, nuclear and other forms of investment by 2030 , when $£ 15$ billion of expenditure on pure, unabated gas...would achieve the same result of keeping the lights on' (HoL, 2014b, p. 275). When combined with the claim that shale gas would be a 'cleaner' form of energy than coal-fired electricity, an appeal could also be made to the current interest of meeting the UK's legislatively mandated GHG emissions reduction targets. Thus, by linking the promotion of shale gas with the existing interests of UK consumers in terms of cheap and accessible energy, fracking proponents were able to position their opponents as acting against the current 
economic interests of UK citizens, while at the same time employing the broader rhetoric of consistency with UK and global climate policy.

Critical voices employed similar scaling seeking to differentiate the economic linkages of fracking advocates through reference to alternative calculations. However, in relation to climate change these statements were comparatively more uncertain and temporally located in longer-term scales. For instance, fracking opponents often struggled to connect the complexity of climate change to recognized tangible interests beyond agreed national emissions targets and a largely unquantified future of dangerous or 'catastrophic climate change' (HoC, 2013a, p. 26). This of course is one of the key problems of engaging people in the need for climate action, in that the issue itself is so nebulous, long-term and complex that making it meaningful for average citizens is often extremely difficult (Moser, 2010). While environmental NGOs and local activists' appeals to future local impacts (such as the depletion of water supplies or the contamination of aquifers and the industrialisation of their countryside) resulted in local council rejections of fracking, these more tangible links were nevertheless located within a future scale that was both indeterminate and uncertain.

Thus, both advocates and opponents of fracking engaged in scalar politics to make interests equivalent at spatial and temporal scales across global, national and local levels. Fracking proponents, such as the UK Government and resource companies, sought to establish the legitimacy of a new fracking industry by seeking equivalence with energy consumers, landholders and workers by appealing to their interests in jobs, cheaper energy and financial incentives. Beyond these economic interests, proponents also invoked interests around climate change action through appeals to emissions mitigation. Combined, these appeals drew heavily on ideals of national consensus. By contrast, fracking opponents, such as environmental NGOs and community groups, sought to highlight conflicts in identities and interests - a logic of difference - that would eventuate from a new fracking industry. Overall, our analysis suggests 
that proponents articulated a broader range of interests for actors to align with than their opponents (see Table 3 and 4). Further, these appeared more temporally immediate and are arguably easier to articulate for alignment with a broad set of tangible interests. Fracking proponents thus used these interests to show how criticism of fracking was not only economically regressive but against the national interest of UK citizens.

\section{Discussion}

Our analysis shows how the public inquiries into fracking were used by proponents to forge linkages through chains of equivalence with interests at different constructed scales. Industries connected to fossil fuel extraction and government can thus be seen as a dominant 'historical bloc' (Gramsci, 1971) favouring fracking. However, rather than connecting their interests with particular groups of actors, this bloc claims to simultaneously represent local, national and global interests. This scaling of interests allows the hegemonic project to discursively support the development of fossil fuels and appear to address climate change. This is possible due to citizens' multiple (and often competing) interests at different scalar 'levels'.

The analysis also demonstrates how opponents of fracking highlighted their difference of interests in constructing a political frontier. In creating their own chain of equivalence, fracking opponents connected their arguments to local demands for protecting the environment and scaled this up to include climate change. Advocates of fracking avoided a confrontation with this opposing formation and instead attempted to accommodate the different interests by expanding the hegemonic formation to include local concerns and climate change demands. Fracking was thus presented as the solution to both immediate local employment needs as well as distant and global climate change concerns.

Drawing on our analysis of the fracking debate in the UK, we offer three contributions to literatures within OMT. First, we contribute to broader discussions on sustainability 
(Banerjee, 2003; Shrivastava, 1995), fossil fuel hegemony (Levy and Egan, 2003; Levy and Spicer, 2013), and the failure to act on climate change (Wright and Nyberg, 2017). While fracking has been rarely investigated within OMT (for an exception see Gond, Barin Cruz, Raufflet and Charron, 2016), the case illustrates the dominance of fossil fuels within energy politics. Despite the urgency of climate change and its dire implications for the future of human civilization, key actors in the inquiries were able to construct climate change as an idealistic rather than practical concern. For instance, in one of the hearings, climate change was even dismissed in questioning expert witnesses: 'Let us leave aside the question of emissions and the global warming' (Lord Lipsey, HoL, 2014b, p. 195). By using fracking to address concerns over energy needs, proponents deflected more radical changes and constructed their position as more reasonable and practical in addressing climate change (Levy, 1997; Prasad and Elmes, 2005). Thus, despite the contestation over fracking, privileged and dominant actors were able to maintain the status quo (that is, the continuation of fossil fuel use) by constructing fracking as unproblematic and climate change as a side issue (Maguire and Hardy, 2009).

This adds to the discussion on climate politics and broader sustainability debates within OMT by demonstrating how fossil fuel hegemony is maintained through the absorption of climate critique (Wright and Nyberg, 2017). The hegemony of fossil fuels can be explained through the coordinated activities of the fossil fuel industry and their political allies in government to establish a historical bloc in promoting fracking as well as the recruitment of allies through (a) financial compensation and (b) strategic accommodations in taking climate change into account (Levy and Egan, 2003). Through the analytical lens of scaling, we show how 'elite actors' in a historical bloc maintain their hegemonic positions in policies on fossil fuel extraction as well as how counter-hegemonic movements have limited scalar reach and efficacy (Ansari, Gray and Wijen, 2011). By constructing equivalence and avoiding establishing a political frontier, we explain how hegemony around a contested issue can be 
established without clear structures of domination in a complex political arena (Schüssler, Rüling and Wittneben, 2014).

Second, while research on climate change within OMT has illustrated both spatial (Wittneben et al., 2012) and temporal (Slawinski et al., 2017) complexities, our analysis shows how scales are employed in environmental politics to delay action on climate change. Although climate change is a present reality (evident in the already warmed planet and extreme weather events), the dominant discourses surrounding climate change are focused on future eventualities. Scaling assists in explaining the large degree of inaction on climate change by highlighting how climate responses can be scaled to span local short-term interests in 'keeping the lights on', with shale gas acting as a medium-term bridge fuel to meet future global climate change targets. These temporal spans come with matching interests in local jobs, national energy security, and addressing the global threat of climate change. Beyond short-termism (Slawinski et al., 2017), the scaling processes explain how linking scales can achieve delay in addressing climate change by structuring climate change discourses to fit shared interests across spatial and temporal scales.

This adds to the current focus in OMT on either the level of the firm or global governance (Schüssler et al., 2014; Wittneben et al., 2012), by showing the connections and relationships between market and non-market forces that shape the governance of climate change. We have paid particular attention to the politics of contestation and representation that shape policies influencing responses to climate change, with the neo-Gramscian perspective explaining how dominant actors can create and maintain a social order that reproduces their dominant positions (Wittneben et al., 2012). Scalar politics sustains fossil fuel hegemony, with the complexity of climate change allowing the issue to be stretched across scales to even include the continued extraction of fossil fuels. 
Finally, we contribute to the understanding of hegemony in political contestations by explaining how dominant actors can produce social consent without consensus, by showing how alliances are established through articulations of identities and interests (Contu et al., 2013; Nyberg et al., 2013). In our case, the public inquiries acted as strategic accommodations (Levy et al., 2016), which allowed the political actors to frame the contestation within each inquiry. The hegemonic project was then mainly about constructing equivalence with the negation of political frontiers or upscaling the frontier to an international level. Scales explain the dynamic possibility in moving the frontier to fit the agenda of dominant actors. By contrast, the counter-hegemonic project struggled to construct a political frontier across scalar levels (Dey et al., 2016). The logic of difference can be accommodated by the hegemonic project, while an opposing chain of equivalence would more forcefully challenge the dominant position. Thus, despite the vast majority of the public opposing fracking (Department for Business Energy \& Industrial Strategy, 2017), those arguing against it were largely dependent on counter-hegemonic practices. As such, scaling is a hegemonic discursive process of articulating and connecting identities and interests in promoting a dominant worldview. This is done by forging links based on claiming to represent the interests of actors across different spatial and temporal scales.

By adding scaling to a neo-Gramscian lens of political contestation (Contu et al., 2013; Dey et al., 2016), we explain how the construction of a topography allows for differentiation between local and global concerns as well as present and future interests. These constructions of scale dominate how social actors make sense of the world and are used in everyday life. They can therefore be used, without displaying their competing logics, in connecting scalar differentiated interests in chains of equivalence. The different scales are weaved together in producing a hegemonic project to appeal to actors' partial interests or identities (Nyberg et al., 2013). For example, while certain citizens might not be concerned by the planetary 
consequences of climate change, they might be interested in local jobs, and vice versa. This explains how chains of equivalence can be stretched without creating 'outsiders' or excluding interests by continuously employing categories of scale in attempts to avoid antagonism. If actors disagree with the political position at a national level, the debate can be up-scaled or down-scaled to fit their interests or identities.

\section{Conclusion}

Our analysis demonstrates the scalar politics involved in spanning different interests. This is evident in the internal contradictions we all experience in regards to climate change - present desires compete against future consequences. For those in developed economies, there are clear tensions between our profligate use of fossil fuel energy and the realization of the catastrophic implications of climate change (Wright and Nyberg, 2015). In the ongoing struggle between consumption and destruction, a false temporal distinction exists that sounds pragmatic but is ultimately idealistic. Using fossil fuels, like shale gas, as a transition energy is based on the idea that climate change is something that will happen in the future, although we watch the current catastrophic implications arrive around the world with increasing frequency and severity.

While climate change politics in many Western economies is currently based on individual fractured interests, the implications for contestation based on interests is also divisive. A key issue in the past regarding fossil fuel development has been that impacts have tended to be localised to particular 'sacrifice zones' (Fox, 1999). However, as Klein (2014) points out, under climate change and the rush to unconventional fossil fuels like shale gas, everywhere potentially becomes a sacrifice zone. Of course, the current distribution of sacrifice still falls upon those who are less economically and politically powerful; note for instance the 
current battles over oil pipelines, mega-coal mining and tar sands where the costs are disproportionately borne by poor and indigenous communities (Banerjee, 2011).

A strong political response to climate change thus requires both vertical and horizontal scalar politics. The problem with vertical scaling is that the complexity and urgency of local issues is often lost in translation. Political decision makers appear dumbfounded in response to climate change and the salience of economic figures and voter polls demanding weekly attention. Horizontal politics have, to date, been more successful in connecting local struggles into global movements. For example, the fossil fuel divestment movement organized by groups such as 350.org engage in horizontal politics by supporting and linking local protests across regions and nations (Ayling and Gunningham, 2015). These movements have had limited success in scaling their politics up to, for example, a global level with restricted access to climate change negotiations. With governments and large corporations continuously resisting much needed climate change action, horizontal organizing appears to offer the most fruitful politics. By avoiding vertical hierarchies, the movement can operate across local political parties, national borders and global international relations. 
Table 1. UK parliamentary inquiries into shale gas fracking

Inquiry 1: House of Commons Energy and Climate Change Committee Inquiry into Shale Gas. (HoC 2011)

- Commenced November 2010

- 36 witnesses; 151 pages of written and oral testimony

- Inquiry report published May 2011

- Government response published July 2011

Inquiry 2: House of Commons Energy and Climate Change Committee Inquiry into the Impact of Shale Gas on Energy Markets. (HoC 2013)

- Commenced September 2012

- 52 witnesses; 193 pages of written and oral testimony

- Inquiry report published April 2013

- Government response published July 2013

Inquiry 3: House of Lords Economic Affairs Committee Inquiry into the Economic Impact on UK Energy Policy of Shale Gas and Oil. (HoL 2014)

- Commenced September 2013

- 83 witnesses; 540 pages of written and oral testimony

- Inquiry report published May 2014

- Government response published June 2014

Inquiry 4: House of Commons Environmental Audit Committee Inquiry into the Environmental Risks of Fracking. (HoC 2015)

- Commenced December 2014

- 76 witnesses; 361 pages of written and oral testimony

- Inquiry report published January 2015

- Government response published March 2015 
Table 2. Actors and positions in UK parliamentary inquiries into fracking

\begin{tabular}{|c|c|}
\hline \multicolumn{2}{|l|}{ Support shale gas expansion } \\
\hline Corporations \& industry groups & $\begin{array}{l}\text { Scottish \& Southern Energy; Scotia Gas Networks; Cuadrilla; Shell International Ltd; ExxonMobil; British } \\
\text { Ceramic Confederation; Chemical Industries Association; Energy and Utilities Alliance; Energy Intensive } \\
\text { Users Group; Energy Networks Association; Oil and Gas UK; Centrica Energy; IGas Energy; INEOS; } \\
\text { Électricité de France (EDF) Energy }\end{array}$ \\
\hline Government \& politicians & $\begin{array}{l}\text { Department of Energy and Climate Change; Rt Hon Michael Fallon MP, Minister for Energy; Rt Hon Owen } \\
\text { Paterson MP, Secretary of State for the Environment, Food and Rural Affairs; Viscount (Matt) Ridley }\end{array}$ \\
\hline Research \& technical groups & $\begin{array}{l}\text { British Geological Survey; Durham Energy Institute; Professor Richard Muller, University of California } \\
\text { Berkeley }\end{array}$ \\
\hline \multicolumn{2}{|c|}{ Ambivalence/caution re shale gas expansion } \\
\hline Corporations \& industry groups & $\begin{array}{l}\text { World Coal Association; Office of Gas and Electricity Markets; The Co-operative Group; Bloomberg New } \\
\text { Energy Finance }\end{array}$ \\
\hline Research \& technical groups & $\begin{array}{l}\text { Grantham Research Institute on Climate Change and the Environment; Professor Dieter Helm, Oxford } \\
\text { University }\end{array}$ \\
\hline \multicolumn{2}{|l|}{ Oppose shale gas expansion } \\
\hline Non-government organisations & $\begin{array}{l}\text { Campaign to Protect Rural England; Friends of the Earth; North West France Branch of Labour International; } \\
\text { Greenpeace UK; World Wildlife Fund }\end{array}$ \\
\hline Government \& politicians & UK Green Party Members of the European Parliament \\
\hline Research \& technical groups & Tyndall Centre for Climate Change Research \\
\hline Local environment groups & $\begin{array}{l}\text { Saltford Environment Group; Frack Free Balcombe Residents Association; Residents' Action on Fylde } \\
\text { Fracking; Concerned Communities of Falkirk; East Kent Against Fracking; Frack Free Ryedale; Frack Off } \\
\text { Fife }\end{array}$ \\
\hline
\end{tabular}


Table 3. Vertical scaling discourses in UK fracking debate

\begin{tabular}{|c|c|c|c|}
\hline \multirow{2}{*}{$\begin{array}{l}\text { Proponents } \\
\text { Interests }\end{array}$} & \multirow[b]{2}{*}{ Indicative quotation } & \multicolumn{2}{|l|}{ Opponents } \\
\hline & & Interests & Indicative quotation \\
\hline \multicolumn{4}{|c|}{ Linking national and local scales } \\
\hline $\begin{array}{l}\text { employment } \\
\text { benefits (short- } \\
\text { term, tangible) }\end{array}$ & $\begin{array}{l}\text { '...there is a benefit in terms of jobs and skills too, which } \\
\text { should not be underestimated.' (John Hayes MP, HoC, 2013b, } \\
\text { p. 59) }\end{array}$ & $\begin{array}{l}\text { harm to local } \\
\text { environment } \\
\text { (long-term, } \\
\text { uncertain) }\end{array}$ & $\begin{array}{l}\text { '...the key issues that we would want to be looked at more } \\
\text { carefully at a local level would include well integrity and the } \\
\text { impact that this can have on groundwater contamination.' } \\
\text { (Mr Molho, WWF- UK, HoL, 2014b, OE p. 195) }\end{array}$ \\
\hline $\begin{array}{l}\text { financial interests } \\
\text { of consumers (near- } \\
\text { term and specific) }\end{array}$ & $\begin{array}{l}\text { 'I think that } £ 100,000 \text { [compensation] for a fractured well will } \\
\text { go some way towards compensating the very immediate local } \\
\text { residents from some of the disruption involved over the period } \\
\text { of the actual fracturing before gas starts to flow.' (Michael } \\
\text { Fallon MP. HoL, 2014b, WE, p. } 165 \text { ) }\end{array}$ & $\begin{array}{l}\text { future interests of } \\
\text { consumers (long- } \\
\text { term, intangible) }\end{array}$ & $\begin{array}{l}\text { 'Bringing the issue back to the UK... a move away from the } \\
\text { fossil fuel system towards one that is based on energy } \\
\text { efficiency and low-carbon energy was in the best interests of } \\
\text { UK consumers in the long run.' (Mr Molho, WWF-UK, HoL, } \\
\text { 2014b, OE, p. 203) }\end{array}$ \\
\hline $\begin{array}{l}\text { energy security/ } \\
\text { cost (near-term and } \\
\text { specific) }\end{array}$ & $\begin{array}{l}\text { 'I don't see a way in which we can meet our security of supply } \\
\text { obligations and try to keep prices affordable without having } \\
\text { hydrocarbons in that mix.' (Simon Toole, HoC, 2011a, OE, } \\
\text { pp. 51-52) }\end{array}$ & & \\
\hline \multicolumn{4}{|c|}{ Linking global and national scales } \\
\hline $\begin{array}{l}\text { energy security/ } \\
\text { independence } \\
\text { (future benefit from } \\
\text { current trade } \\
\text { relations) }\end{array}$ & $\begin{array}{l}\text { 'It would reduce imports and help maintain security of supply. } \\
\text { This would be especially valuable given the continuing fall in } \\
\text { output from the North Sea and Europe's reliance on Russia, its } \\
\text { biggest gas supplier, highlighted by the crisis in Ukraine.' } \\
\text { (HoL, 2014b, p. 5) }\end{array}$ & $\begin{array}{l}\text { economic well- } \\
\text { being (long-term, } \\
\text { uncertain) }\end{array}$ & $\begin{array}{l}\text { '...allowing unchecked shale gas exploration could leave the } \\
\text { UK economy over-dependent on fossil fuel extraction and } \\
\text { over-exposed to the economic impacts on the fossil fuel } \\
\text { industry of global action to tackle climate change' (FoTE, } \\
\text { Greenpeace, WWF-UK, HoL, 2014b, W.E, p. 183) }\end{array}$ \\
\hline
\end{tabular}


national emission commitments (sho

'This [shale gas extraction] will of course be in a way that is

to medium-term

tangible)

change targets' (Defra, DECC and DCLG, HoC, 2015, WE, p. 3)

Linking local and global scales emissions

reduction, energy

costs (short-term,

tangible)

employment

benefits (long-term

tangible)
'Gas is generally considered a 'clean fuel' as a result of having lower carbon emissions than other solid and liquid fuels when combusted. Its use, particularly in the domestic arena, is almost always associated with being more energy efficient and also more cost effective than equivalent electric or oil fired systems' (Scotia Gas Networks, HoC, 2011b, p.

11)

'Overall the IoD identified the potential opportunity in the North West of England for local communities to replicate the 'Aberdeen effect' and develop a local onshore gas and oil exploration and production expertise which could lead the development of these industries elsewhere in the UK and across Europe.' (Cuadrilla, HoL, 2014b, p. 65) climate change impact (long-

term, uncertain)
'So my concerns around the expansion of shale gas are similar to concerns around the expansion of any new fossil fuel resources - that we would be adding to the total burden that we place on the atmosphere and on the climate system.' (Dr Broderick, HoC, 2015, OE, p. 3 ) climate change impact (medium to long-term, tangible)

energy costs (medium to longterm, uncertain)
'Several counties in the UK are water stressed, Kent among them, and climate change is likely to increase drough problems' (East Kent against Fracking, HoC, 2015, WE, p. 2) '...there is a serious danger that UK consumers, growing increasingly concerned about their domestic energy bills, may press for shale gas to substitute for renewables which they see (probably incorrectly) as being responsible for these higher energy bills' (Professor Paul Stevens, HoL, 2014b WE p. 490) 
Table 4. Horizontal scaling discourses in UK fracking debate

\begin{tabular}{llll}
\hline $\begin{array}{l}\text { Proponents } \\
\text { Interests }\end{array}$ & Indicative quotation & Opponents & Interests \\
\hline
\end{tabular}

\section{Linking national scales}

energy cost,

(contemporary

analogy, tangible)

examples first, shale gas has lowered prices, secondly, gas is

already being used as an alternative to liquid hydrocarbon

fuels, offering reductions in emissions' (INEOS, HoC, 2013a,

WE, p. 35)

emissions reduction

(contemporary

analogy, tangible)

Assuming climate change objectives are to reduce GHG emissions then it has been demonstrated that USA has reduced

CO2 energy-related emissions to a 20-year low.' (Scotia Gas

Networks, HoC, 2013a, WE, p. 55)
GHG emissions

(long-term,

uncertain)

economic risk

(contemporary

analogy, tangible)

environmental

protection

(contemporary

analogy, tangible)

local environment

(short-medium

term, tangible)
'... at the moment it is fairly clear that if we burn more indigenous gas here, that other gas will be burnt elsewhere and the carbon dioxide emissions will just go up.' (Professor Anderson, HoC, 2013b, OE, p.30)

'The situation in Poland, where an industry has already moved into reverse simply because Polish gas is not

economic at current prices is a warning of the economic risk of UK shale.' (FoTE, Greenpeace, WWF-UK, HoL, 2014b, WE, p.183)

'...already of course, a number of countries in Europe have already banned exploitation of shale gas.' (Mr Bennett, HoL, 2014b, OE, p.207)

Linking local scales

energy security

'Natural gas can help to meet the demand for cleaner energy

(short to medium

in many sectors' (Oil and Gas UK, HoC, 2013a, WE, p.47)
Even without taking into account possible contamination issues, shale gas production is clearly likely to be highly disruptive to local communities and have a negative impact on local roads, buildings adjacent to access roads, noise levels and air quality.' (WWF-UK, HoC, 2011a. WE, p.105) 


\section{References}

Ansari, S., B. Gray and F. Wijen (2011). 'Fiddling while the ice melts? How organizational scholars can take a more active role in the climate change debate', Strategic Organization, 9, pp. 70-76.

Ayling, J. and N. Gunningham (2015). 'Non-state governance and climate policy: The fossil fuel divestment movement', Climate Policy, 10.1080/14693062.2015.1094729.

Banerjee, S. B. (2000). 'Whose land is it anyway? National interest, indigenous stakeholders, and colonial discourses the case of the Jabiluka uranium mine', Organization \& Environment, 13, pp. 3-38.

Banerjee, S. B. (2003). 'Who sustains whose development? Sustainable development and the reinvention of nature', Organization Studies, 24, pp. 143-180.

Banerjee, S. B. (2011). 'Voices of the governed: Towards a theory of the translocal', Organization, 18, pp. 323-344.

Barley, S. R. (2010). 'Building an institutional field to corral a government: A case to set an agenda for organization studies', Organization Studies, 31, pp. 777-805.

Brown, A. D. (2000). 'Making sense of inquiry sensemaking', Journal of Management Studies, 37, pp. 45-75.

Brown, J. C. and M. Purcell (2005). 'There's nothing inherent about scale: Political ecology, the local trap, and the politics of development in the brazilian amazon', Geoforum, 36, pp. 607-624.

Bulkeley, H. and P. Newell (2015). Governing climate change, Routledge, Abingdon.

Contu, A., F. Palpacuer and N. Balas (2013). 'Multinational corporations' politics and resistance to plant shutdowns: A comparative case study in the south of France', Human Relations, 66, pp. 363-384.

Department for Business Energy \& Industrial Strategy (2017). Energy and climate change public attitude tracker, wave 22: https://www.gov.uk/government/statistics/energyand-climate-change-public-attitudes-tracker-wave-22

Department of Energy and Climate Change (2010). The unconventional hydrocarbon resources of britain's onshore basins - shale gas, DECC, London.

Dey, P., H. Schneider and F. Maier (2016). 'Intermediary organisations and the hegemonisation of social entrepreneurship: Fantasmatic articulations, constitutive quiescences, and moments of indeterminacy', Organization Studies, 37, pp. 14511472.

Fox, J. (1999). 'Mountaintop removal in West Virginia: An environmental sacrifice zone', Organization \& Environment, 12, pp. 163-183. 
Gond, J.-P., L. Barin Cruz, E. Raufflet and M. Charron (2016). 'To frack or not to frack? The interaction of justification and power in a sustainability controversy', Journal of Management Studies, 53, pp. 330-363.

Goodall, A. H. (2008). 'Why have the leading journals in management (and other social sciences) failed to respond to climate change?', Journal of Management Inquiry, 17, pp. 408-420.

Gramsci, A. (1971). Selections from the prison notebooks, International Publishers, New York.

Grant, D., C. Hardy, C. Oswick and L. Putnam (2004). 'Organizational discourse: Exploring the field'. In: D. Grant, C. Hardy, C. Oswick and L. Putnam (eds.), Handbook of organizational discourse. pp. 1 - 36. London: Sage.

Haarstad, H. (2014). 'Climate change, environmental governance and the scale problem', Geography Compass, 8, pp. 87-97.

Herod, A. (2011). Scale, Routledge, Abingdon.

Hoffman, A. J. (2005). 'Climate change strategy: The business logic behind voluntary greenhouse gas reductions', California Management Review, 47, pp. 21-46.

House of Commons (2011a). Shale gas: Fifth report of session 2010-12: Volume I: Report, together with formal minutes, oral and written evidence, HC 795, http://www.publications.parliament.uk/pa/cm201012/cmselect/cmenergy/795/795.pdf

House of Commons (2011b). Shale gas: Fifth report of session 2010-12: Volume II: Additional written evidence, https://www.gov.uk/government/uploads/system/uploads/attachment_data/file/79187/ scishalegasvol2.pdf

House of Commons (2013a). The impact of shale gas on energy markets: Seventh Report of Session 2012-13 Volume II, Additional written evidence, http://www.publications.parliament.uk/pa/cm201213/cmselect/cmenergy/785/785vw. pdf

House of Commons (2013b). The impact of shale gas on energy markets: Seventh Report of Session 2012-13 Volume I, HC 785, http://www.publications.parliament.uk/pa/cm201213/cmselect/cmenergy/785/785.pdf

House of Commons (2015). Environmental risks of fracking: Eighth Report of Session 201415, HC 856, http://www.publications.parliament.uk/pa/cm201415/cmselect/cmenvaud/856/856.pdf

House of Lords (2014a). The economic impact on UK energy policy of shale gas and oil: $3 r d$ Report of Session 2013-14, HL Paper 172, http://www.publications.parliament.uk/pa/ld201314/ldselect/ldeconaf/172/172.pdf

House of Lords (2014b). The economic impact on UK energy policy of shale gas and oil: Oral and written evidence: http://www.parliament.uk/documents/lordscommittees/economic-affairs/EnergyPolicy/EAC-energy-ev-vol.pdf 
Howard-Grenville, J., S. J. Buckle, B. J. Hoskins and G. George (2014). 'Climate change and management', Academy of Management Journal, 57, pp. 615-623.

Howarth, D. (2015). 'Gramsci, hegemony and post-Marxism'. In: M. McNally (ed.) Antonio gramsci. pp. 195-213. Basingstoke: Palgrave Macmillan.

Howarth, D. and Y. Stavrakakis (2000). 'Introducing discourse theory and political analysis'. In: D. Howarth, A. J. Norval and Y. Stavrakakis (eds.), Discourse theory and political analysis: Identities, hegemonies and social change. pp. 1-23. Manchester: Manchester University Press.

IPCC (2013). Climate change 2013: The physical science basis. Working group I contribution to the fifth assessment report of the Intergovernmental Panel on Climate Change, Cambridge University Press, Cambridge.

IPCC (2014). Climate change 2014: Mitigation of climate change. Contribution of working group III to the fifth assessment report of the Intergovernmental Panel on Climate Change, Cambridge University Press, Cambridge.

Jaspal, R. and B. Nerlich (2014). 'Fracking in the UK press: Threat dynamics in an unfolding debate', Public Understanding of Science, 23, pp. 348-363.

Jowit, J. and H. Gersmann (2011). 'Fracking 'probable' cause of Lancashire quakes', The Guardian, 2 November, https://www.theguardian.com/environment/2011/nov/02/fracking-cause-lancashirequakes

Kitchen, C. (2014). To the ends of the earth: A guide to unconventional fossil fuels, Corporate Watch, London.

Klein, N. (2014). This changes everything: Capitalism vs. The climate, Simon \& Schuster, New York.

Laclau, E. (2005). On populist reason, Verso, London.

Laclau, E. and C. Mouffe (2001). Hegemony and socialist strategy: Towards a radical democratic politics, Verso, London.

Leitner, H. (1997). 'Reconfiguring the spatiality of power: The construction of a supranational migration framework for the European union', Political Geography, 16, pp. 123-143.

Levy, D., J. Reinecke and S. Manning (2016). 'The political dynamics of sustainable coffee: Contested value regimes and the transformation of sustainability', Journal of Management Studies, 53, pp. 364-401.

Levy, D. L. (1997). 'Environmental management as political sustainability', Organization \& Environment, 10, pp. 126-147.

Levy, D. L. and D. Egan (2003). 'A neo-Gramscian approach to corporate political strategy: Conflict and accommodation in the climate change negotiations', Journal of Management Studies, 40, pp. 803-829. 
Levy, D. L. and P. J. Newell (2002). 'Business strategy and international environmental governance: Toward a neo-Gramscian synthesis', Global Environmental Politics, 2 , pp. 84-101.

Levy, D. L. and A. Spicer (2013). 'Contested imaginaries and the cultural political economy of climate change', Organization, 20, pp. 659-678.

Maguire, S. and C. Hardy (2009). 'Discourse and deinstitutionalization: The decline of DDT', Academy of Management Journal, 52, pp. 148-178.

Mann, M. (2014). 'False hope: The rate of global temperature rise may have hit a plateau, but a climate crisis still looms in the near future', Scientific American, 310, pp. 78-81.

Marston, S. A. (2000). 'The social construction of scale', Progress in Human Geography, 24, pp. 219-242.

Moore, A. (2008). 'Rethinking scale as a geographical category: From analysis to practice', Progress in Human Geography, 32, pp. 203-225.

Moser, S. C. (2010). 'Communicating climate change: History, challenges, process and future directions', Wiley Interdisciplinary Reviews: Climate Change, 1, pp. 31-53.

New, M., D. Liverman, H. Schroeder and K. Anderson (2011). 'Four degrees and beyond: The potential for a global temperature increase of four degrees and its implications', Philosophical Transactions of the Royal Society A: Mathematical, Physical and Engineering Sciences, 369, pp. 6-19.

Nyberg, D., A. Spicer and C. Wright (2013). 'Incorporating citizens: Corporate political engagement with climate change in Australia', Organization, 20, pp. 433-453.

O’Doherty, D. (2015). 'Missing connexions: The politics of airport expansion in the United Kingdom', Organization, 22, pp. 418-431.

Prasad, P. and M. Elmes (2005). 'In the name of the practical: Unearthing the hegemony of pragmatics in the discourse of environmental management', Journal of Management Studies, 42, pp. 845-867.

Schüssler, E., C.-C. Rüling and B. B. F. Wittneben (2014). 'On melting summits: The limitations of field-configuring events as catalysts of change in transnational climate policy', Academy of Management Journal, 57, pp. 140-171.

Shrivastava, P. (1995). 'The role of corporations in achieving ecological sustainability', Academy of Management Review, 20, pp. 936-960.

Slawinski, N., J. Pinkse, T. Busch and S. B. Banerjee (2017). 'The role of short-termism and uncertainty avoidance in organizational inaction on climate change: A multi-level framework', Business \& Society, 56, pp. 253-282.

Spicer, A. (2006). 'Beyond the convergence-divergence debate: The role of spatial scales in transforming organizational logic', Organization Studies, 27, pp. 1467-1483. 
Spicer, A. and P. Fleming (2007). 'Intervening in the inevitable: Contesting globalization in a public sector organization', Organization, 14, pp. 517-541.

Springer, S. (2014). 'Human geography without hierarchy', Progress in Human Geography, 38, pp. 402-419.

Swyngedouw, E. and N. C. Heynen (2003). 'Urban political ecology, justice and the politics of scale', Antipode, 35, pp. 898-918.

Topal, C. (2009). 'The construction of general public interest: Risk, legitimacy, and power in a public hearing', Organization Studies, 30, pp. 277-300.

van Bommel, K. and A. Spicer (2011). 'Hail the snail: Hegemonic struggles in the slow food movement', Organization Studies, 32, pp. 1717-1744.

Van der Byl, C. A. and N. Slawinski (2015). 'Embracing tensions in corporate sustainability: A review of research from win-wins and trade-offs to paradoxes and beyond', Organization \& Environment, 28, pp. 54-79.

Walton, S. and B. Boon (2014). 'Engaging with a Laclau \& Mouffe informed discourse analysis: A proposed framework', Qualitative Research in Organizations and Management: An International Journal, 9, pp. 351-370.

Whiteman, G., B. Walker and P. Perego (2013). 'Planetary boundaries: Ecological foundations for corporate sustainability', Journal of Management Studies, 50, pp. 307336.

Wittneben, B. B. F., C. Okereke, S. B. Banerjee and D. L. Levy (2012). 'Climate change and the emergence of new organizational landscapes', Organization Studies, 33, pp. 14311450 .

Wodak, R. (2004). 'Critical discourse analysis'. In: C. Seale, G. Gobo, J. F. Gubrium and D. Silverman (eds.), Qualitative research practice. pp. 197-213. London: Sage.

Wright, C. and D. Nyberg (2015). Climate change, capitalism and corporations: Processes of creative self-destruction, Cambridge University Press, Cambridge.

Wright, C. and D. Nyberg (2017). 'An inconvenient truth: How organizations translate climate change into business as usual', Academy of Management Journal, 60, pp. 1633-1661.

Wright, C., D. Nyberg, C. De Cock and G. Whiteman (2013). 'Future imaginings: Organizing in response to climate change', Organization, 20, pp. 647-658. 